Tersedia online di: http://ejournal-balitbang.kkp.go.id/index.php/jra

\title{
PERFORMA REPRODUKSI DAN LARVA IKAN GABUS (Channa striata Blkr) DENGAN BEBERAPA TEKNIK PEMIJAHAN
}

\author{
Wahyulia Cahyanti”, Adang Saputra, dan Anang Hari Kristanto \\ Balai Riset Perikanan Budidaya Air Tawar dan Penyuluhan Perikanan \\ Jl. Sempur No. 1, Bogor
}

(Naskah diterima: 22 Maret 2021; Revisi final: 9 Juni 2021; Disetujui publikasi: 10 Juni 2021)

\begin{abstract}
ABSTRAK
Sejumlah penelitian terhadap ikan gabus (Channa striata Blkr) telah dilakukan mulai dari pembenihan dan pembesaran, namun masih belum banyak informasi ilmiah terkait performa reproduksi dan larva yang dihasilkan baik dari pemijahan alami maupun pemijahan semi-alami (induksi hormonal). Penelitian ini bertujuan untuk menentukan teknik pemijahan yang tepat untuk ikan gabus. Dalam penelitian ini digunakan induk jantan dan betina dengan tingkat kematangan gonad (TKG) yang seragam (yaitu pada TKG-IV). Penelitian memakai empat perlakuan stimulasi hormon, yaitu A (kontrol, tanpa stimulasi hormon), B (induk jantan dan betina distimulasi hormon), $\mathrm{C}$ (induk betina distimulasi hormon), D (induk jantan distimulasi hormon). Hormon yang digunakan untuk menginduksi induk betina dan jantan adalah LHRHa + anti dopamin. Masing-masing perlakuan menggunakan tiga pasang induk. Parameter performa reproduksi yang diamati meliputi fekunditas, diameter telur, lama waktu menetas, dan volume kuning telur. Untuk performa larva dilakukan pengamatan laju penyerapan kuning telur, pertumbuhan panjang dan bobot larva, laju pertumbuhan spesifik, dan sintasan. Dari penelitian diperoleh bahwa ikan perlakuan-A dan B mampu berovulasi hingga menetas, perlakuan-C berhasil ovulasi namun gagal menetas, sedangkan perlakuan-D tidak mampu ovulasi. Fekunditas dan derajat penetasan hasil pemijahan alami paling tinggi $(1.832 \pm 13$ butir dan $97,20 \pm 2,49 \%$. Namun, waktu ovulasi dan waktu menetas pemijahan alami $(159,50$ \pm 0,50 jam dan $3.210,00 \pm 5,00$ menit) lebih lama dibanding pemijahan buatan $(26,00 \pm 2,00$ jam dan $2.370 .00 \pm 15,00$ menit). Abnormalitas terjadi pada perlakuan-B $(1,30 \pm 0,42 \%$, sedangkan larva hasil perlakuan-A tidak ada yang abnormal. Berdasarkan hasil penelitian ini selain pemijahan alami, ikan gabus dapat dipijahkan secara buatan melalui stimulasi hormon pada induk jantan dan betina.
\end{abstract}

\section{KATA KUNCl: ikan gabus; larva; pemijahan; telur}

\section{ABSTRACT: Reproduction and larval performance of snakehead fish (Channa striata Blkr) using different breeding techniques. By: Wahyulia Cahyanti, Adang Saputra, and Anang Hari Kristanto}

\begin{abstract}
Various studies on snakehead fish (Channa striata Blkr) have been carried out from breeding, nursery, to grow-out. Nevertheless, information regarding reproductive performance and produced larvae either from natural spawning or semi-natural (hormonal induction) spawning are still limited in the literature. This study aimed to determine the appropriate spawning technique for snakehead fish. In this study, the fish males and females were used with a uniform gonad maturity level. The study used four hormone stimulation treatments, namely: A (control, without hormone stimulation), B (male and female parents were hormone-stimulated), C (hormone-stimulated female parent), D (hormone-stimulated male parent). The hormone used to induce female and male broodstock was LHRHa + anti-dopamine. Each treatment used three pairs of parents. Parameters of reproductive performance observed included fecundity, egg diameter, hatching time, and egg yolk volume. For larval performance, observations were made of the rate of egg yolk absorption, growth in length and weight of larvae, specific growth rate, and survival. The research found that fish in treatment-A and B were able to ovulate, and the produced eggs could hatch. Fish in treatment- $C$ managed to ovulate but failed to hatch, while treatment-D could not ovulate. The fecundity
\end{abstract}

\footnotetext{
\# Korespondensi: Balai Riset Perikanan Budidaya Air Tawar dan

Penyuluhan Perikanan

Jl. Sempur No. 1, Bogor, Indonesia

E-mail: wahyulia.cahyanti@gmail.com
} 
Performa reproduksi dan larva ikan gabus (Channa striata Blkr) ..... (Wahyulia Cahyanti)

and hatching rates of the natural spawning were the highest $(1,832 \pm 13$ grains and $97.20 \pm 2.49 \%$. However, the time of ovulation and hatching time for natural spawning (159.50 \pm 0.50 hours and 3,210.00 \pm 5.00 minutes) were longer than those of artificial spawners $(26.00 \pm 2.00$ hours and 2,370.00 \pm 15.00 minutes). Abnormalities occurred in treatment-B (1.30 $\pm 0.42 \%$, while the larvae from treatment-A were normal. Based on the results of this study, in addition to natural spawning, snakehead fish can be spawned artificially through hormonal stimulation of male and female broodstock.

\section{KEYWORDS: eggs; larvae; seedings; snakehead fish}

\section{PENDAHULUAN}

Ikan gabus (Channa striata Blkr.) merupakan ikan air tawar yang dapat ditemukan di seluruh wilayah Indonesia (Asfar et al., 2014). Ikan gabus memiliki banyak nama daerah seperti ikan bocek (Riau), ikan kutuk (Jawa), haruan (Kalimantan), bale salo/bale bolong (Bugis), kanjilo (Makassar), Gastor (Sentani, Papua), dan Iain-lain (Asfar, 2012; Tawali et al., 2012). Ikan gabus merupakan salah satu ikan budidaya potensial (Gustiano et al., 2015) karena bernilai ekonomis tinggi, memiliki pasar prospektif, dan tingkat konsumsi masyarakat lokal yang tinggi. Nilai ekonomis ikan gabus tergambar dari harganya yang berkisar antara Rp25.000,00-Rp45.000,00 untuk ikan segar dan Rp35.000,00-Rp60.000,00 untuk ikan kering (Bijaksana, 2010). Konsumsi ikan gabus segar tertinggi di Indonesia adalah Kalimantan Tengah dengan angka konsumsi sebesar 5,21 kg/kapita/tahun; sedangkan serapan ikan gabus asin/diawetkan adalah Jawa Barat, sebesar 3.193 ton dalam satu tahun. Tingkat serapan ikan menggambarkan besarnya pasar yang ada di suatu wilayah.

Permintaan ikan gabus semakin meningkat karena selain untuk konsumsi (BPS, 2013), juga digunakan sebagai bahan medis. Ikan gabus dimanfaatkan dalam bidang kesehatan yang disebut sebagai medicinal freshwater fish, seperti digunakan untuk mempercepat proses penyembuhan luka pasca-o perasi dan melahirkan (Rahayu et al., 2016). Ikan gabus memiliki manfaat biomedik yang sangat menguntungkan, seperti antiradang, antijasad renik, antinyeri nosisepsi (nociception), dan sifat antikanker (Hue et al., 2017). Ikan gabus mengandung protein yang tinggi terutama albumin, asam amino esensial, asam lemak esensial, mineral khususnya zink/seng (Zn), dan beberapa vitamin yang bagus dalam proses penyembuhan luka dan kesehatan (Shafri \& Abdul, 2012; Mustafa et al., 2012). Selain itu, secara klinis intervensi konsentrat protein ikan gabus dalam bentuk suplemen telah membantu mempercepat penyembuhan pasien pasca-operasi, luka bakar, dan stroke pada pasien rawat inap di rumah sakit (Tawali et al., 2012). Sebuah penelitian menyebutkan bahwa jumlah protein albumin ikan gabus mencapai 1,15 \pm

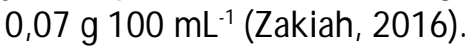

Teknologi domestikasi ikan gabus telah dinyatakan berhasil (KEPMEN KP, 2015). Namun upaya produksi ikan gabus yang kontinu dan terukur tidak mudah jika hanya bergantung pada proses pemijahan secara alami. Aplikasi hormon dalam pemijahan ikan gabus merupakan alternatif produksi benih dalam jumlah besar (At-Thar et al., 2017). Sejumlah penelitian telah dilakukan mulai dari pembenihan dan pembesaran, namun masih belum banyak informasi ilmiah terkait performa telur dan larva yang dihasilkan baik dari pemijahan alami maupun pemijahan semi-alami (induksi hormonal). Oleh karena itu, perlu untuk membandingkan data performa kedua metode pemijahan tersebut sebagai acuan dalam upaya peningkatan ketersediaan benih ikan gabus. Penelitian ini bertujuan untuk menentukan teknik pemijahan yang tepat untuk ikan gabus.

\section{BAHAN DAN METODE}

\section{Pembenihan Ikan Gabus}

Penelitian dilakukan di Instalasi Penelitian Plasma Nutfah Perikanan Air Tawar, Cijeruk, Bogor, Jawa Barat. Ukuran induk jantan yang digunakan adalah (panjang $20,13 \pm 1,109 \mathrm{~cm}$; bobot 101,25 \pm 4,349 g), dan betina adalah (panjang 18,50 $\pm 1,080 \mathrm{~cm}$; bo bot 91,00 $\pm 1,826 \mathrm{~g}$ ). Induk ikan dipelihara pada kolam terpal berukuran $3 \mathrm{~m} \times 3 \mathrm{~m} \times 1 \mathrm{~m}$ secara terpisah antara jantan dan betina untuk proses pematangan gonad. Masing-masing kolam maksimal diisi 10 ekor induk jantan dan 10 ekor induk betina. Ikan gabus tersebut diberi pakan secara teratur setiap pagi dan sore hari dengan pelet berkadar protein 30\% dan dosis $5 \%$ biomassa per hari. Setiap induk diperiksa secara berkala untuk melihat tingkat kematangan gonadnya (untuk betina dilakukan metode kanulasi, sedangkan jantan dengan pengamatan fisik (meliputi warna tubuh, serta warna dan bentuk genital papilanya). Suhu air pada kolam penelitian terendah mencapai $22^{\circ} \mathrm{C}$ dan tertinggi $28^{\circ} \mathrm{C}$. Permukaan air bak diberi naungan berupa tanaman eceng gondok sebanyak $50 \%$ dari luas permukaan kolam sebagai media tempat bertelurnya ikan gabus.

Induk-induk yang siap pijah kemudian dipisahkan dan diberok pada bak fiber berdiameter $60 \mathrm{~cm}$. Setelah siap, dilakukan penimbangan untuk mengetahui bobot 
ikan sekaligus menentukan jumlah hormon yang akan diberikan (untuk pemijahan semi-alami). Jenis hormon yang digunakan adalah LHRHa + anti dopamin dengan merek dagang ovaprim. Penyuntikan ovaprim memakai dosis $0,6 \mathrm{~mL} \mathrm{~kg}^{-1}$ bobot ikan sekali injeksi. Ikan yang telah disuntik tersebut dipijahkan pada kolam pemijahan $2 \mathrm{~m} \times 2 \mathrm{~m} \times 1 \mathrm{~m}$, dengan perbandingan 1:1. Pada kolam pemijahan diberi substrat tempat meletakkan telur dan busa ikan. Substrat yang digunakan adalah tanaman air eceng gondok sekitar $10 \%$ dari luas permukaan. Penelitian memakai empat perlakuan, yaitu A (kontrol, tanpa stimulasi hormon), B (induk jantan dan betina distimulasi hormon), C (induk betina distimulasi hormon), D (induk jantan distimulasi hormon) dengan masing-masing perlakuan menggunakan tiga pasang induk.

Pemijahan ikan ditandai dengan muncul sedikit busa di sekitar tanaman eceng gondok (substrat). Pada saat tersebut, substrat harus sering dicek (setiap enam jam sekali), mengingat ukuran telur ikan gabus yang kecil, warnanya yang bening, serta tipe telurnya yang mengambang. Setelah terjadi pemijahan dan diperoleh telur, induk diambil dan telur diinkubasi pada baskom berdiameter $50 \mathrm{~cm}$ dengan tinggi air $20 \mathrm{~cm}$ tanpa aerasi untuk pengamatan. Baskom diberi aerasi lemahsedang (cukup gelembung namun tidak sampai ada putaran air) untuk menambah pasokan oksigen selama proses inkubasi. Setelah telur menetas, larva tidak diberi pakan sampai kuning telurnya habis. Setelah kuning telur habis (sekitar dua hari), larva diberi pakan udang renik (Artemia sp.) sampai berumur dua minggu, dan minggu-minggu berikutnya diberi pakan komersial berbentuk serbuk berkadar protein $40 \%$ secara ad satiation. Kualitas air dijaga dengan sistem pergantian air setiap minggu sebanyak $50 \%$

\section{Parameter yang Diamati}

\section{Fekunditas}

Telur uji yang digunakan adalah telur ikan gabus hasil dari pemijahan alami dan semi-alami (kedua induk diinduksi hormon). Telur hasil pemijahan dihitung secara manual untuk mengetahui data fekunditas (jumlah telur yang ovulasi).

\section{Lama Waktu Menetas dan Derajat Penetasan}

Setiap pemijahan yang berhasil, diambil sampel telur sebanyak masing-masing 50 butir untuk diukur diameternya. Sisa telur dari masing-masing perlakuan kemudian diinkubasi pada tiga wadah penetasan sebagai ulangan. Masing-masing ulangan menggunakan 500 butir telur. Sisanya ditebar pada wadah lain yang lebih besar. Parameter yang diamati pada tahap ini adalah lama waktu menetas dan derajat penetasan.

\section{Laju Penyerapan Kuning Telur}

Setelah telur menetas, larva dari setiap ulangan tersebut, diambil sampel masing-masing sebanyak 25 butir untuk diukur panjang dan bobot awalnya. Untuk pengamatan volume kuning telur dan laju penyerapan kuning telur diambil lagi masing-masing 25 ekor untuk diukur diameter kuning telurnya sebanyak dua kali (awal menetas dan pada jam keenam).

Volume kuning telur dihitung menggunakan rumus Hemming \& Buddlington (1988):

$$
\mathrm{V}=0.1667 \pi \mathrm{LH}^{2}
$$

$V=0,1667 \grave{A} L H^{2}$

di man:

$V=$ volume kuning telur $\left(\mathrm{mm}^{3}\right)$

$\mathrm{L}=$ diameter kuning telur memanjang $(\mathrm{mm})$

$\mathrm{H}=$ diameter kuning telur memendek $(\mathrm{mm})$

Laju penyerapan kuning telur (LPKT) dihitung menggunakan rumus Kendall et al. (1984):

$$
\mathrm{LPKT}=\frac{\mathrm{Vo}-\mathrm{Vt}}{\mathrm{T}}
$$

di mana:

$V_{0}=$ volume kuning telur awal $\left(\mathrm{mm}^{3}\right)$

$\mathrm{Vt}=$ volume kuning telur akhir $\left(\mathrm{mm}^{3}\right)$

$\mathrm{T}=$ waktu (jam)

\section{Pertumbuhan dan Sintasan Larva}

Ikan uji yang digunakan adalah larva ikan gabus hasil dari pemijahan alami dan semi-alami. Pakan yang digunakan dalam pemeliharaan adalah naupli Artemia dan pakan komersial berupa pelet halus dengan protein $>40 \%$ secara ad satiation dengan frekuensi tiga kal i sehari. Tebar awal larva adalah 250 ekor per wadah (berupa bak fiber berdiameter $60 \mathrm{~cm}$ dengan ketinggian air $100 \mathrm{~cm}$ ) dan diulang tiga kali per perlakuan. Sampling larva dilakukan tujuh hari sekali selama 21 hari pemeliharaan. Parameter yang diukur meliputi pertumbuhan panjang, bobot, Iaju pertumbuhan spesifik (SGR), dan sintasan (SR).

\section{Analisis Data}

Analisis statistik menggunakan piranti lunak SPSS ver 16 menggunakan uji Duncan dengan tingkat kepercayaan $95 \%$

\section{HASIL DAN BAHASAN}

Performa reproduksi dan telur ikan gabus pada penelitian ini ditampilkan pada Tabel 1. Data tersebut menggambarkan bahwa setiap metode pemijahan menunjukkan performa yang berbeda-beda. 
Tabel 1. Data reproduksi dan performa terlur ikan gabus dengan metode pemijahan berbeda

Table 1. Reproduction and larval performance of snakehead fish artificially spawned with different spawning methods

\begin{tabular}{|c|c|c|c|c|}
\hline \multirow{2}{*}{$\begin{array}{l}\text { Parameter } \\
\text { Parameters }\end{array}$} & \multicolumn{4}{|c|}{ Perlakuan (Treatments) } \\
\hline & A & B & C & D \\
\hline $\begin{array}{l}\text { Jumlah Induk (pasang) } \\
\text { Numbers of broothstock (pairs) }\end{array}$ & 3 & 3 & 3 & 3 \\
\hline $\begin{array}{l}\text { Jumlah induk Memijah (pasang) } \\
\text { Spawned (pairs) }\end{array}$ & 3 & 3 & 1 & - \\
\hline $\begin{array}{l}\text { Waktu ovulasi (jam) } \\
\text { Ovulation time (hours) }\end{array}$ & $159.50 \pm 0.50^{\mathrm{a}}$ & $26.00 \pm 2.00^{b}$ & $26.50 \pm 1.50^{b}$ & - \\
\hline $\begin{array}{l}\text { Fekunditas (butir } 100 \mathrm{~g}^{-1} \text { ) } \\
\text { Fecundity (eggs } 100 \mathrm{~g}-1 \text { ) }\end{array}$ & $2,012.82 \pm 12.58^{\mathrm{a}}$ & $1,533.73 \pm 5.51^{b}$ & $410.25 \pm 24.21^{c}$ & - \\
\hline $\begin{array}{l}\text { Diameter telur terbuahi } \\
\text { Fertilized egg diameter (mm) }\end{array}$ & $1.51 \pm 0.046^{\mathrm{a}}$ & $1.53 \pm 0.043^{\mathrm{a}}$ & $1.52 \pm 0.050^{\mathrm{a}}$ & - \\
\hline $\begin{array}{l}\text { Waktu menetas (menit) } \\
\text { Hatch time (minutes) }\end{array}$ & $3,210.00 \pm 5.00^{\mathrm{a}}$ & $2,370.00 \pm 15.00^{b}$ & - & - \\
\hline $\begin{array}{l}\text { Volume kuning telur } \\
\text { Yolk volume }\left(\mathrm{mm}^{3}\right)\end{array}$ & $0.17 \pm 0.015^{a}$ & $0.16 \pm 0.02^{\mathrm{a}}$ & - & - \\
\hline $\begin{array}{l}\text { Waktu habis kuning telur (menit) } \\
\text { Egg yolk run time (minutes) }\end{array}$ & $2,718.33 \pm 23.63^{a}$ & $3,273.33 \pm 29.30^{b}$ & - & - \\
\hline $\begin{array}{l}\text { Laju penyerapan kuning telur }\left(\mathrm{mm}^{3} \mathrm{jam}^{-1}\right) \\
\text { Egg yolk absorption rate }\left(\mathrm{mm}^{3} \mathrm{~h}^{-1}\right)\end{array}$ & $0.010 \pm 0.0030^{\mathrm{a}}$ & $0.008 \pm 0.0031^{b}$ & - & - \\
\hline $\begin{array}{l}\text { Derajat penetasan } \\
\text { Hatching rate }(\%)\end{array}$ & $97.20 \pm 2.50^{\mathrm{a}}$ & $82.67 \pm 2.38^{b}$ & - & - \\
\hline
\end{tabular}

Keterangan: A (kontrol, tanpa stimulasi hormon), B (induk jantan dan betina distimulasi hormon), C (induk betina distimulasi hormon), D (induk jantan distimulasi hormon); huruf superskrip di balik nilai standar deviasi yang berbeda di baris yang berbeda menunjukkan efek yang berbeda secara signifikan (uji Duncan, $P<0,05$ )

Note: $\quad$ A (control, without hormone stimulation), B (hormone-stimulated male and female parents), C (hormonestimulated female parent), D (hormone-stimulated male parent); different superscript letters after standard deviation values in the same row show significant differences (Duncan's test, $\mathrm{P}<0.05$ )

Pada penelitian ini, diperoleh hasil di mana induk perlakuan-A, B, dan C dapat berovulasi, sedangkan perlakuan-D tidak dapat berovulasi. Waktu ovulasi pada perlakuan-B dan C relatif cepat yaitu antara 26,00 \pm 2,00 jam dan tidak berbeda nyata $(P<0,05)$. Waktu ovulasi pada perlakuan-A jauh lebih lama yaitu 159,50 $\pm 0,50$ jam; di mana perlakuan-A (kontrol) berbeda nyata dengan perlakuan-B dan $C$. Hormon yang banyak berperan untuk pematangan gonad adalah follicle stimulating hormone (FSH), sedangkan $\mathrm{GnRH}$ analog umumnya berperan dalam proses ovulasi ini yang diduga sebagai penyebab ikan yang dipijahkan secara alami lebih lama ovulasi dibanding ikan yang diinduksi hormon Ovaprim. Berdasarkan penelitian Jamlaay et al. (2016) ikan gabus yang diberi perlakuan hormon Prostaglandin $2 \pm$ (PGF2 \pm ) berovulasi 9,17-12,24 jam pasca-suntik, nilai ini lebih cepat dibanding kontrol yaitu 22,67 jam. Dalam penjelasannya, Jamlaay et al. (2016) mengemukakan bahwa penggunaan hormon meningkatkan kerja otak dalam proses ovulasi jika dibanding kontrol yang hanya mengandalkan hormon ovulasi alami. Ovaprim merupakan hormon sintetis yang mengandung LHRH analog dan anti dopamin. Sehingga ikan yang disuntik ovaprim diharapkan meningkat kadar LH-nya. Hormon LH yang tinggi akan memicu ovulasi. Mardhatillah et al. (2018) yang menyatakan bahwa cepatnya ovulasi disebabkan karena kandungan LH yang tinggi dalam darah akibat penyuntikan hormon.

Demikian halnya dengan waktu menetas, di mana perlakuan-A lebih lama menetas dibandingkan perlakuan-B. Hal tersebut diduga karena pengaruh pemberian hormon (Jamlaay et al., 2016). Penyuntikan hormon ovulasi merupakan teknik pemaksaan telur untuk keluar dari kantung telur. Ikan yang memijah alami, akan berovulasi pada waktu terbaiknya sedangkan ikan yang diinduksi hormon dipaksa untuk mengeluarkan telurnya dengan lebih cepat. Sehingga 
meski sama-sama mengeluarkan telur, ikan yang memijah alami lebih lambat waktu ovulasinya begitu pula dengan waktu menetasnya. Hal ini diduga akibat adanya proses hormonal yang memengaruhi kinerja dalam proses pembuahan sekaligus penetasan (Dhewantara, 2013).

Waktu ovulasi dan waktu menetas berbanding terbalik dengan fekunditas yang dihasilkan. Pada perlakuan-A, jumlah total telur yang diovulasikan lebih banyak $\left(2.012,82 \pm 12.583\right.$ butir $\left.100 \mathrm{~g} \mathrm{bobot}^{-1}\right)$ jika dibandingkan dengan perlakuan-B dan C. Pada perlakuan-C, jumlah telur yang diovulasikan yaitu 410,25 \pm 24.214 butir $100 \mathrm{~g}^{-1}$, namun keseluruhan telur tidak menetas. Hal ini diduga karena ikan betina dalam kondisi yang dipaksakan, sedangkan ikan jantan belum siap spermanya, sehingga kemungkinan besar telur tidak sempat terbuahi. Salah satu faktor internal yang berperan signifikan dalam memengaruhi penetasan telur ikan adalah kualitas telur. Jika kualitas telur kurang baik maka telur akan sulit dibuahi, berkembang, dan kemudian menetas. Menurut Dhewantara (2013), pembuahan menjadi indikator kualitas telur, di mana kemampuan telur berkembang menjadi embrio setelah terjadi pembuahan hingga menetas sangat dipengaruhi oleh reaksi-reaksi dalam telur itu sendiri.

Telur merupakan hasil akhir dari proses gametogenesis, setelah oosit mengalami fase pertumbuhan yang panjang dan tergantung pada gonadotropin. Perkembangan diameter telur disebabkan karena akumulasi kuning telur selama proses vitelogenesis sampai tahap akhir perkembangan telur yang ditandai oleh terbentuknya lapisan khorion. Semakin berkembang gonad ikan, diameter telur yang berkembang di dalamnya semakin besar (Harianti, 2012). Diameter telur dan volume kuning telur antar perlakuan tidak berbeda nyata. Kuning telur pada larva hasil pemijahan alami lebih cepat habis dibandingkan pemijahan dengan penyuntikan hormon. Derajat penetasan antara kedua perlakuan tersebut juga berbeda, di mana pada perlakuan-A telur lebih banyak menetas $(97,20 \pm 2,498 \%$ dibanding perlakuan $B$ $(82,67 \pm 2,376 \%$. Derajat penetasan dipengaruhi oleh beberapa faktor seperti pakan induk yang digunakan, kualitas induk, suhu, pH, air media, dan intensitas cahaya (Adipu \& Rovik, 2018). Suhu pada kolam pemijahan berkisar antara $25^{\circ} \mathrm{C}-30^{\circ} \mathrm{C}$, dengan $\mathrm{DO}$ antara 5-7 mg/L. Nilai tersebut masih cukup baik pada pemijahan ikan. Kolam pemijahan merupakan kolam terpal yang diam tanpa aliran, ditambah lagi kondisi cuaca dan curah hujan saat penelitian yang tidak menentu. Menurut Altiara et al. (2016), pH sangat memengaruhi penetasan ikan gabus. Penelitian tersebut menerangkan bahwa nilai derajat penetasan akan mencapai angka di atas $80 \%$ jika $\mathrm{pH}$ air berkisar 7-8 dan akan mencapai di atas 90\% pada pH 9. Perbedaan perlakuan stimulasi hormon pada induk ikan gabus berdampak signifikan pada performa larva yang dihasilkan. Performa larva pada setiap perlakuan ditunjukkan pada Tabel 2, sedangkan pertumbuhan larva ditunjukkan pada Gambar 1 dan 2.

Pertumbuhan mutlak dan sintasan antara perlakuanA dan B menunjukkan nilai yang tidak berbeda nyata. Sedangkan nilai laju pertumbuhan spesifik baik panjang maupun bobot, perlakuan-A sedikit lebih besar dibanding perlakuan-B. Suhu air yang berkisar $27^{\circ} \mathrm{C}$ $28^{\circ} \mathrm{C}$ diduga adalah suhu optimal dan menjadi faktor yang menentukan bagi pertumbuhan. Saputra (2018) pemeliharaan larva ikan gabus pada suhu air $27^{\circ} \mathrm{C}$ memberikan bobot individu terbaik dibandingkan dengan perlakuan lainnya $\left(25^{\circ} \mathrm{C}, 29^{\circ} \mathrm{C}\right.$ dan $\left.31^{\circ} \mathrm{C}\right)$. Pada suhu terlalu rendah, enzim pencernaan, dan enzimenzim pengatur lainnya memiliki aktivitas yang rendah sehingga berdampak terhadap tingkat metabolisme, kondisi ini berdampak terhadap rendahnya laju pertumbuhan (Werner, 2004), yang pada akhirnya menyebabkan bobot ikan rendah. Pada suhu air terlalu tinggi, aktivitas enzim relatif lebih tinggi.

Sintasan yang dihasilkan pada penelitian ini sedikit lebih kecil dari penelitian sebelumnya, menurut AthThar et al. (2017), nilai sintasan pada pemijahan alami induk ikan gabus hasil tangkapan alam berkisar antara 81\%88\% Berdasarkan nilai abnormalitas larva, pada pemijahan alami tidak ditemukan larva yang abnormal dan pada pemijahan melalui stimulasi hormon diperoleh $1,30 \pm 0,423 \%$ larva yang abnormal. Penyebab abnormalitas diduga dipengaruhi oleh faktor pemaksaan (penyuntikan hormon) yang membuat perkembangan saat embriologi berlangsung mengalami gangguan. Abnormalitas juga memengaruhi nilai sintasan. Pada penelitian ini perlakuan-B (memiliki larva abnormal) sintasannya lebih kecil bila dibandingkan kontrol. Hal ini sesuai dengan Aidil et al. (2016) yang menyatakan abnormalitas yang terjadi pada larva ikan lele Sangkuriang berdampak pada rendahnya tingkat sintasan larva.

Kedua grafik (Gambar 1 dan 2) menggambarkan pola pertumbuhan dari larva ikan gabus, di mana pertumbuhan baik panjang maupun bobot menunjukkan garis linier (meningkat seiring bertambahnya waktu). Pada awal penelitian larva kedua perlakuan memiliki panjang dan bobot yang sama, namun seiring berjalannya waktu penelitian larva 
Tabel 2. Performa larva ikan gabus dengan metode pemijahan berbeda yang dipelihara selama 21 hari

Table 2. The performance of snakehead fish larvae with different spawning methods during 21 days rearing period

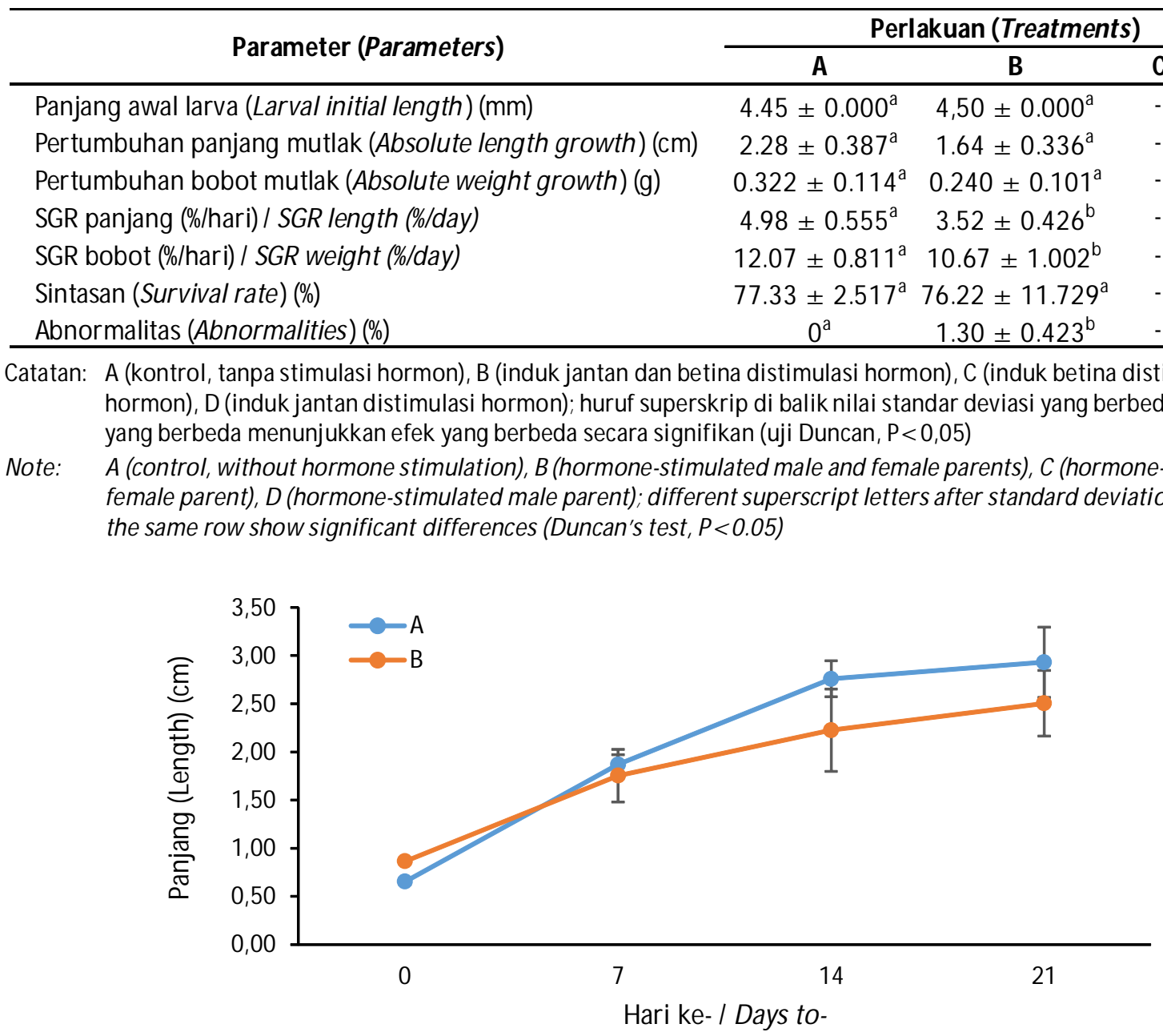

Gambar 1. Pertumbuhan panjang larva gabus selama 21 hari pemeliharaan (A : kontrol, B : induk jantan dan betina distimulasi hormon).

Figure 1. Weekly measured length growth of snakehead larvae for 21 days of rearing (A : control; B : hormone-stimulated male and female parents).

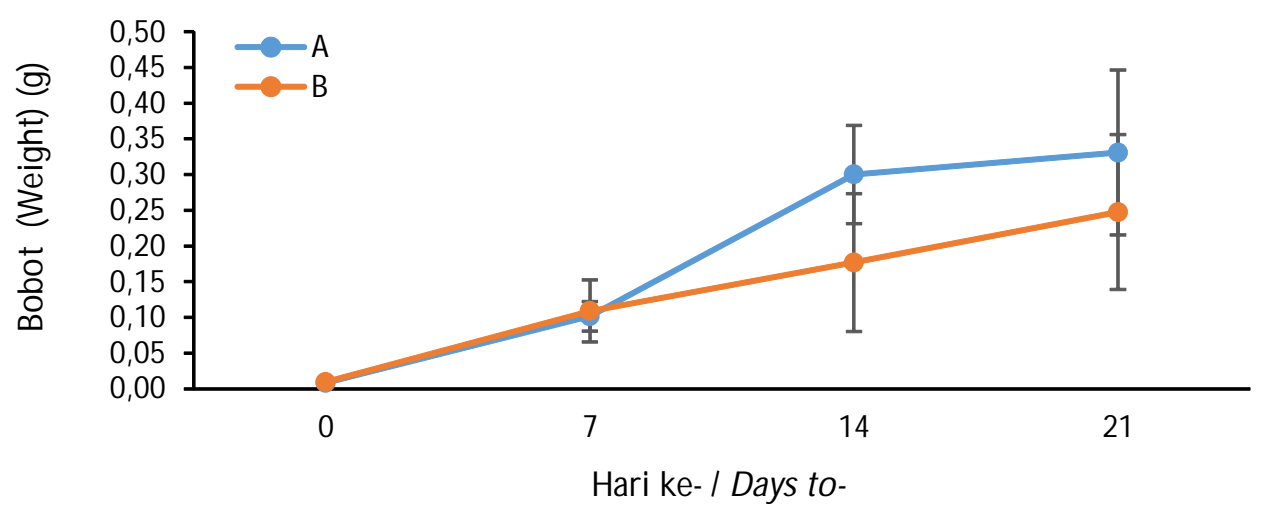

Gambar 2. Pertumbuhan bobot larva gabus selama 21 hari pemeliharaan (A : kontrol; $B$ : induk jantan dan betina distimulasi hormon).

Figure 2. Weekly measured weight growth of snakehead larvae for 21 days of rearing(A : control; B : hormone-stimulated male and female parents). 
perlakuan-A tumbuh lebih cepat dibanding perlakuan$B$ meskipun nilai keduanya saling tidak berbeda nyata.

\section{KESIMPULAN}

Pemijahan ikan gabus berhasil dilakukan melalui pemijahan alami dan semi-alami. Kualitas telur dan larva yang dihasilkan pada pemijahan alami (tanpa stimulasi hormon) lebih baik dibanding semi-alami (dengan stimulasi hormon), namun produksi larva akan lebih cepat jika menggunakan stimulasi hormon. Pemijahan ikan gabus melalui stimulasi hormon LHRHa + antidopamin pada induk jantan dan betina menghasilkan waktu ovulasi dan waktu menetas yang lebih cepat dibanding kontrol. Perbaikan teknik pemijahan melalui stimulasi hormon masih diperlukan untuk meningkatkan laju penyerapan kuning telur, laju pertumbuhan harian, dan derajat penetasan, serta untuk menurunkan tingkat abnormalitas larva.

\section{UCAPAN TERIMA KASIH}

Penulis mengucapkan terima kasih yang sebesarbesarnya pada Instalasi Riset Plasma Nutfah Perikanan Air Tawar, Cijeruk, Balai Riset Perikanan Budidaya Air Tawar dan Penyuluhan Perikanan (BRPBATPP), Bogor atas segala fasilitas yang telah digunakan dalam penelitian ini. Teknisi, serta Mahasiswa Universitas Muhammadiyah Malang yang telah membantu secara teknis selama penelitian ini berlangsung.

\section{DAFTAR ACUAN}

Adipu, Y. \& Rovik, A. (2018). Performa kualitas telur ikan gabus (Channa striata Blkr) dengan pemberian pakan berbeda dal am wadah terkontrol. Gorontalo Fisheries Journal, 1(1), 70-79.

Altiara, A., Muslim, \& Fitrani, M. (2016). Presentase penetasan telur ikan gabus (Channa striata) pada $\mathrm{pH}$ air yang berbeda. Jurnal Akuakultur Rawa Indonesia, 4(2), 140-151.

Asfar, M. (2012). Optimalisasi ekstraksi albumin ikan gabus (Channa Striatus) dan pemurnian pada titik isoelektriknya. Universitas Hasanuddin, Makassar.

Asfar, M., Tawali, A.B., Abdullah, N., \& M ahendradatta, M. (2014). Extraction of albumin of snakehead fish (Channa striatus) in producing the fish protein consentrate (FPC). International Journal of Scientific \& Technology Research, 3(4), 85-88.

Ath-Thar, M.H.F., Gustiano, R., Kusmini, I.I., Prakoso, V.A., \& Putri, F.P. (2017). Induksi hormonal maturasi gonad ikan gabus (Channa striata). Jurnal Riset Akuakultur, 12(1), 9-20.

Badan Pusat Statistik [BPS]. (2013). Survei sosial ekonomi 2013: Preferensi ikan rumah tangga nasional. Jakarta.
Bijaksana, U. (2010). Kajian fisiologi reproduksi ikan gabus, Channa striata Blkr di dalam wadah dan perairan rawa sebagai upaya domestikasi. IPB, Bogor.

Aidil, D., Zulfahmi, I., \& Muliari. (2016). Pengaruh suhu terhadap derajat penetasan telur dan perkembangan larva ikan lele Sangkuriang (Clarias gariepinus var. Sangkuriang). Jesbio ${ }_{\perp}$ 5(1), 30-33.

Dhewantara, Y.L. (2013). Induksi ovulasi dan pemijahan pada ikan patin siam (Pangasius hypopthalmus) dengan manipulasi hormon. IPB, Bogor.

Gustiano, R., Kusmini, I.I., \& Ath-thar, M.H.F. (2015). Mengenal sumber daya genetik ikan spesifik lokal air tawar Indonesia. (1st ed.). Indonesia: IPB Press.

Harianti. (2012). Fekunditas dan diameter telur ikan gabus (Channa striata Bloch, 1793) di Danau Tempe, Kabupaten Wajo. Jurnal Saintek Perikanan, $8(2), 18-24$.

Hemming, T.A. \& Buddington, R.K. (1988). Yolk absorption in embrionic and larvae fishes. p. 407445. In Hoar, W.S. \& Randall (Eds.). Fish Physiology. Vol. XI. New York: Academic Press, p. 178253.

Hue, J., Pan, H., Liang, W., Xiao, D., Chen, X., Guo, M., \& He, J. (2017). Prognostic effect of albumin to globulin ratio in patients with solid tumors: A systematic review and meta-analysis. Journal of Cancer, 8(19), 4002-4010.

Jamlaay, F., Widodo, M.S., \& Faqih, A.R. (2016). Ovulation time and ovulated eggs count of sneakhead Channa striata induce by prostaglandin $2 \pm$ with different doses. Jurnal Akuakultur Indonesia, 15(1), 89-92.

Kendall, A.W.Jr. (1984). Identification of fish eggs. $p$. 27-31. In Ontogeny and systematics of fishes. Moser, H.G., Richards, W.J., Cohen, D.M., Fahay, M.P., Kendall, A.W.Jr., \& Richardson, S.L. (Eds.). Amer. Soc. Ich. and Herp. Spec. Pub., No. 1.

KEPMEN KP. (2015). Keputusan Menteri Kelautan dan Perikanan Republik Indonesia Nomor 18/ KEPMENKP/2015 tentang Pelepasan ikan gabus Haruan. Kementerian Kelautan Perikanan.

Mardhatillah, H., Efrizal, \& Rahayu, R. (2018). Pengaruh ekstrak kelenjar hipofisa ayam broiler dalam mempercepat respons ovulasi ikan koi Cyprinus carpio L. Jurnal Metamorfosa, 5(1), 28-35.

Mustafa, A., Widodo, M.A., \& Kristianto, Y. (2012). Albumin and zinc content of snakehead fish (Channa striata) extract and its role in health. IEESE International Journal of Science and Technology (IJSTE), 1(2), 1-8. 
Rahayu, P., Marcelline, F., Sulistyaningrum, E., Suhartono, M.T., \& Tjandrawinata, R.R. (2016). Potential effect of striatin (DLBS0333), a bioactive protein fraction isolated from Channa striata for wound treatment. Asian Pac. J. Trop. Biomed., (6)12, 1001-1007.

Saputra, A. (2018). Teknologi produksi benih ikan gabus Channa striata melalui pendekatan fisiologi, manajemen pakan dan rekayasa lingkungan. IPB, Bogor.

Shafri, M.A.M. \& Abdul, M.M.J. (2012). Therapeutic potential of the haruan (Channa striatus): from food to medicinal uses. Malaysian Journal of Nutrition, 18(1), 125-136.
Tawali, A.B., Roreng, M.K., Mahendradatta, M., \& Suryani. (2012). Difusi teknologi produksi konsentrat protein dari ikan gabus sebagai food supplement di Jayapura. Proceeding Ristek Insinas, hlm. 243-247.

Werner, R.G. (2004). Freshwater fishes of Northeastern United States: A field guide. New York: State Series.

Zakiah, A.F.N. (2016). Analisis DNA mitokondria dan profil protein beberapa ikan air tawar Indonesia. IPB, Bogor. 